\title{
Frascati: An Apotheosis of Topography (Frascati. Apoteoza topografii)
}

Author: Ewa Kuryluk

First Published: 2009

About the Author: Ewa Kuryluk was born in 1946 in Cracow. She is known as an artist and pioneer of textile installation and air art, painter, photographer, novelist and author of essays. She taught at New School for Social Research, New York University and University of California, San Diego. She exhibited her works in Europe and the United States.

Further Important Publications: Century 21 (1992, in Poland Wiek 21, 1995; Wiek 21. Trio dla ukrytych napisane po polsku w roku 2000, 2000; novel); Ludzie z powietrza. Retrospektywa 1959-2002: instalacje, fotografie, rysunki, obrazy (2002, Air People. Retrospective 1959-2002: installations, photographs, drawings, paintings); Goldi. Apoteoza zwierzaczkowatości (2004, Goldi: An Apotheosis of Animalisation; autobiography); Feluni. Apoteoza enigmy (2019, Feluni: An Apotheosis of Enigma; autobiography).

\section{Content and Interpretation}

Frascati is the second part of the family trilogy which also includes Goldi and Feluni. The first part was dedicated to the author's father Karol Kuryluk (known as Łapka), and the third to the author's brother, Piotr, who was called Feluni. The collective hero of all the stories is the post-war Polish-Jewish intelligentsia: Karol Kuryluk was the editor of Polish reviews, later a minister and diplomat; his wife came from a Jewish family, wrote prose and translated.

Frascati continues the most important plots of Goldi - the secret of hidden Jewish ancestry, as well as the trauma that is associated with it and passes down from generation to generation. The source of the Kuryluk tragedy is primarily Maria's silence about the Jewish origin of her parents, the Kohany family, and withholding her first marriage with Teddy Gleich.

The narrative is not a chronological representation of the facts, but rather represents the problems of daughters living in the shadow of their mothers' Holocaust experiences, which is characteristic for second-generation women's narratives. It can be juxtaposed with A Family History of Fear (Rodzinna historia lęku) by Agata Tuszyńska, Where She Came From by Helen Epstein or After Long Silence by Helen Felmont. A common feature of these stories, in addition to the genre that Tomasz Łysak described as second-generation autobiography, is the children's sudden discovery that their parents are of Jewish origin, a fact that was kept secret as they feared for their lives during the Holocaust.

Ә Open Access. ( 2021 Marta Tomczok, published by De Gruyter. (c) BY-NC-ND This work is licensed under a Creative Commons Attribution-NonCommercial-NoDerivatives 4.0 License. https://doi.org/10.1515/9783110671056-044 
The situation described in Frascati reflects the term described by Barbara Kessel as "Suddenly Jewish" - an identity built around a discovery that was made after reaching adulthood. By writing down fictitious and probable conversations with her mother, Kuryluk tries to present the story of her mother's stay in the Lviv Ghetto, her escape and survival, parting with her first husband, romance and marriage with Kuryluk, the first years of illness which came after the liberation, her trips abroad, difficult motherhood and worsening of mental illness in parallel with her brother's Piotr growing up and his serious illness (schizophrenia). Although it is a difficult story and sometimes tragic, it does not lack a sense of humour, and its brilliant and ironic dialogues are characteristic for Ewa Kuryluk's literature, full of metaphors and allusions to the cultural heritage of Europe. Moreover, Kuryluk tells the intellectual history of the Polish People's Republic, which was co-created by her father. The keynote of the story is the illness of her brother, multi-talented Piotr, who was devastated by the Holocaust.

As the subtitle indicates, Frascati is a story about a place. Firstly, about an elite district of Warsaw, an area that was gardens in the eighteenth century. It was there that the Kuryluk family settled in 1947, turning a tattered three-room apartment into a cultural centre of the prewar capital of Poland. Secondly, it is a story about Lviv: in 2008 the writer goes there in the footsteps of her mother, taking photos of places related to Miriam Kohana's stay in the ghetto and on the Aryan side.

The book contains almost 60 photographs from private archives, of buildings, from newspaper clippings, of children's drawings and works of art. Just like in W. G. Sebald's prose, they create a well-thought-out narrative, developed with great expertise that supplements the words of the characters.

\section{Main Topics and Problems}

Unlike in the works of Epstein, Tuszyńska, Tulli ( $\rightarrow$ Italian High Heels) or Bożena Umińska Keff ( $\rightarrow$ A Piece about Mother and Fatherland), Kuryluk tells the story of a relationship between a survivor and her daughter without conflicts or tensions (Łysak, 2009, pp. 195-208). She presents the family story merging with the general history of the family and the country, describes multiple political and cultural contexts, combined with verbal and visual narration. She manages to avoid criticism of Poles, and provides no descriptions of antisemitism or analysis of mutual resentments. Therefore, each part of the trilogy goes beyond the Holocaust and has suprahistorical significance, often embedded in the rich tradition of cultural topics. Here are two examples of how the subject of the Holocaust is enhanced. The first of these is through the motif of the stultifera navis (ship of fools), which in the Middle Ages was used to transport mentally ill people out of the city. An image of this is in one of the pictures in Kuryluk's book. This work was dedicated to the mother and brother of the author - two people suffering from a mental illness. The other topos is the image of a psychiatric hospital as a ghetto. Kuryluk arranges the facts with their perception and combines different images, not only to create an artistic history of madness (modelled on Mi- 
chael Foucault's History of Madness), but also to make the Holocaust part of the humanities and to try to describe it using existing literature.

In Frascati, animals are important characters, especially birds and animals of the Warsaw zoo where Jews were hiding during the war. The Kuryluk family pets, a dog and a hamster, also play a key role. Kuryluk is one of the first artists who departed from writing about the Holocaust from a purely human perspective and saw an opportunity in the posthumanist statement that during the war, we were done with homo sapiens. This also explains the writer's use of animal masks (similar to the masks worn by the characters in some of her photographs): her father is Łapka (a dog's name, which means paw), her brother is Crab Kępka, she is a Kangaroo herself. As in her previous books, the author combines different narratives, times and materials. This hyper-realistic simultaneity also serves to maintain the impression that the conversation between the writer and her mother, who died in 2001, is still going on.

\section{Cited Works}

Łysak, T. (2009). Meandry ujawniania - późne odkrycie tożsamości w Rodzinnej historii lęku Agaty Tuszyńskiej. In: P. Czapliński, E. Domańska, eds., Zagłada. Współczesne problemy rozumienia i przedstawiania. Poznań: Wydawnictwo Poznańskie Studia Polonistyczne, pp. 195-208. http://www.kuryluk.art.pl/. [Accessed: 12.12.2019]

\section{Further References}

Artwińska, A. (2012). Miejsca. O przestrzeni w twórczości Ewy Kuryluk. In: H. Gosk, ed., Narracje migracyjne w literaturze polskiej XX i XXI wieku. Kraków: Universitas, pp. 241-257. Cuber, M. (2013). Metonimie Zagłady. O polskiej prozie lat 1987-2012. Katowice: Wydawnictwo Uniwersytetu Śląskiego. Epstein, H. (2010). Children of the Holocaust: Conversations with Sons and Daughters of Survivors. Lexington: Plunkett Lake Press. Shallcross, B. (1991). Ewa Kuryluk: Skinscripts Chronicle the Body's Journey. Fiberarts, 18(1). Stankowska, A. (2019). Ikona i trauma. Pytania o „obraz prawdziwy“ w liryce i sztuce polskiej drugiej połowy XX wieku. Kraków: Universitas. 